REVIEW ARTICLE

\title{
Piperine: Old Spice and New Nutraceutical?
}

Katarina Smilkov $^{\mathrm{a}, *}$, Darinka G. Ackova ${ }^{\mathrm{a}}$, Aleksandar Cvetkovski ${ }^{\mathrm{a}}$, Tatjana Ruskovska ${ }^{\mathrm{b}}$, Bojana Vidovic $^{\mathrm{c}}$ and Mustafa Atalay ${ }^{\mathrm{d}}$

${ }^{a}$ Department of Pharmacy, Faculty of Medical Sciences, Goce Delcev University, Stip, North Macedonia; ${ }^{b}$ Department of General Medicine, Faculty of Medical Sciences, Goce Delcev University, Stip, North Macedonia; ${ }^{c}$ Department of Bromatology, Faculty of Pharmacy, University of Belgrade, Belgrade, Serbia; ${ }^{d}$ Institute of Biomedicine, School of Medicine, University of Eastern Finland, Kuopio, Finland

Abstract: Background: Many of the activities associated with pepper fruits have been attributed to piperine, the most active compound present in these spices.

Objective: This paper aims to provide an overview of the known properties of piperine, i.e. piperine's chemistry, its physiological activity, documented interactions as a bioenhancer and reported data concerning its toxicity, antioxidant properties and anticancer activity.

\section{A R T I C L E H IS T O R Y}

Received: May 21, 2019

Accepted: June 19, 2019

DOI:

$10.2174 / 1381612825666190701150803$

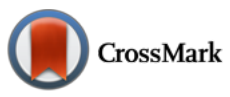

Discussion: It is known that piperine possesses several properties. In its interaction with other drugs, it can act as a bioavailability enhancer; this effect is also manifested in combination with other nutraceuticals, e.g. with curcumin, i.e. piperine can modify curcumin's antioxidant, anti-inflammatory, antimicrobial and anticancer effects. Piperine displays significant immunomodulating, antioxidant, chemopreventive and anticancer activity; these effects have been shown to be dose-dependent and tissue-specific. However, the main limitation associated with piperine seems to be its low bioavailability, a disadvantage that innovative formulations are overcoming.

Conclusion: It is predicted that an increasing number of studies will focus on piperine, especially those directed towards unraveling its properties at molecular level. The current knowledge about the action of piperine will form a foundation for ways to improve piperine's bioavailability e.g. exploitation of different carrier systems. The therapeutical applications of this compound will be clarified, and piperine will be recognized as an important nutraceutical.

Keywords: Piperine, nutraceutical, characteristics, interactions, enhancer, antioxidant, anticancer.

\section{INTRODUCTION}

\subsection{Nutraceuticals: An Overview}

The link between diet and health has been known since ancient times. Hippocrates wrote about 2500 years ago "Let food be thy medicine and medicine be thy food"; this continues to be relevant today [1]. However, with the advancement of food science and nutrition, the role of diet has changed from simply preventing nutritional deficiencies in promoting optimal well-being and improving the quality of human life [2].

For example, the prolongation in lifespan has increased interest in the role of diet in the prevention of age- related chronic diseases as well as reducing healthcare costs [3].

In the mid-1980s, the concept of functional foods was developed [4]. These are foods which when consumed as a part of a regular diet, may exert beneficial effects, e.g. they may act on one or more targets or functions [5]. Similarly, some types of unmodified whole, processed, enhanced or fortified food can be considered as functional foods [6]. Several years later, Dr. De Felice introduced the term "nutraceutical" as "a food or part of a food that provides medicinal and health benefits, including the prevention and/or treatment of a disease" [7]. At present, in the absence of clear and universally accepted definitions, there is an overlap between nutraceuticals and functional food, and this passes over to other health-related food products [8]. Therefore, in addition to nutraceuticals, dietary supplements can also be viewed as functional

*Address correspondence to this author at the Department of Pharmacy, Faculty of Medical Sciences, Goce Delcev University, P.O.Box: 201, Stip, Republic of North Macedonia; Tel: + 389-70-322-842;

E-mails: katarina.smilkov@ugd.edu.mk; k.smilkov@gmail.com
[9]. These products represent concentrated forms of natural bioactive substances in a suitable pharmaceutical form but they are used in dosages that exceed those that can be obtained from a regular $\operatorname{diet}[10]$.

In addition to nutrients such as vitamins, minerals, amino acids, peptides, and some fatty acids, there are other specific bioactive compounds that can be considered as nutraceuticals: enzymes, preand probiotics, coenzyme Q10, glucosamine, chondroitin, etc., as well as many phytochemicals (polyphenols, sulfur-containing compounds, alkaloids, terpenoids etc.) $[11,12]$. There are several ways to classify nutraceuticals i.e. based on the bioactive compounds present $[3,13,14]$ and their functions [3, 9]; according to their origin $[1,3,8,9]$; their concentrated sources $[1,9]$; mechanisms of actions and health benefits $[1,3,14,15]$ or their chemical nature $[1$, $9,15]$. Nutraceutical classifications can also be based on nutraceutical bioaccessibility, absorption, or chemical transformation within the gastrointestinal tract, as these can be factors limiting their oral bioavailability [16]. Additionally, nutraceuticals can be classified into potential and/or established nutraceuticals according to their proven beneficial effects as demonstrated in either preclinical or clinical studies [17]. At present, only probiotics, prebiotics, omega3 acids, and antioxidants have been placed in the category of established nutraceuticals [18]. Therefore, it is evident that problems are encountered in classifying nutraceuticals, i.e. one substance can be placed into one or more categories. Table 1 lists several nutraceuticals categorized according to their chemical and biological properties $[11,13,14,19]$.

In addition to their sensory properties, the herbs and spices in our diet are rich sources of different phytochemicals with putative beneficial effects e.g. antioxidative, anti-inflammatory, chemopreventive, antimutagenic, immune-modulatory properties [20-22]. 
Table 1. Classification of nutraceuticals.

\begin{tabular}{|c|c|c|c|}
\hline \multicolumn{4}{|c|}{ Nutraceuticals } \\
\hline \multicolumn{3}{|c|}{ According to Chemical Composition } & $\begin{array}{l}\text { According to Effects Against a } \\
\text { Specific Disease }\end{array}$ \\
\hline $\begin{array}{c}\text { Nutrients } \\
\text { (chemical substances with } \\
\text { established nutritional } \\
\text { functions) }\end{array}$ & $\begin{array}{c}\text { Herbs* } \\
\text { (herbs and herb parts as concentrates, ex- } \\
\text { tracts...) }\end{array}$ & $\begin{array}{l}\text { Dietary supplements } \\
\text { (products - tablets, capsules, liquids, powders, } \\
\text { etc., administered orally to enrich the diet) }\end{array}$ & $\begin{array}{c}\text { Cardiovascular protective agents } \\
\text { Antidiabetic agents } \\
\text { Antiobesity agents } \\
\text { Anticancer agents } \\
\text { Antidepressive agents }\end{array}$ \\
\hline $\begin{array}{c}\text { Vitamin } \mathrm{A} \\
\text { Complex B vitamins }\left(\mathrm{B}_{1} \text {, }\right. \\
\left.\mathrm{B}_{2}, \mathrm{~B}_{3}, \mathrm{~B}_{6}\right) \\
\text { Vitamin } \mathrm{C} \\
\text { Vitamin } \mathrm{K} \\
\text { Folic acid } \\
\text { Minerals }(\mathrm{Ca}, \mathrm{Fe}, \mathrm{Mg}, \mathrm{P}, \\
\mathrm{Cr}, \mathrm{Co}, \mathrm{Cu}, \mathrm{Zn}, \mathrm{I}) \\
\text { Amino acids } \\
\text { Fatty acids }\end{array}$ & $\begin{array}{c}\text { Aloe (Aloe vera L.) } \\
\text { Garlic (Allium sativum L.) } \\
\text { Curcumin (Curcuma longa) } \\
\text { Green tea (Camelia sinensis) } \\
\text { Echinacea (Echinacea purpurea L.) } \\
\text { Ginkgo (Ginkgo biloba L.) } \\
\text { St. John's wort (Hypericum perforatum L.) } \\
\text { Chamomile (Matricaria recutita L.) } \\
\text { Melissa (Melissa officinalis L.) } \\
\text { Ginseng (Panax ginseng) } \\
\text { Black pepper (Piper nigrum) } \\
\text { Valerian (Valeriana oficinalis L.) } \\
\text { Ginger (Zingiber officinale Rosc.) }\end{array}$ & 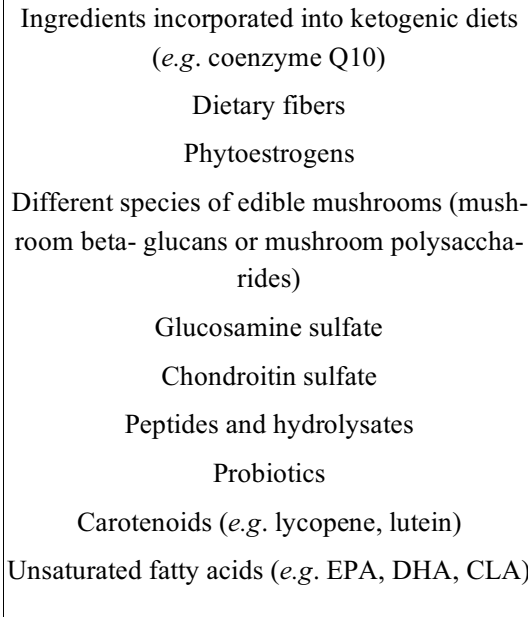 & $\begin{array}{l}\text { Agents with effects on osteoarthri- } \\
\text { tis and other conditions affecting } \\
\text { the musculoskeletal system }\end{array}$ \\
\hline
\end{tabular}

*Selection has been based on the most frequent use (adapted with modifications from $[11,13,14,19]$ ).

Due to their potent biological activities and low or non- existent side effects, some of these phytochemicals are being investigated in preclinical and clinical trials as a new approach to treating diseases $[23,24]$ or as lead compounds in the design of innovative drugs [25]. Moreover, there is evidence that some phytochemicals can enhance the bioefficacy of drugs like antimicrobials, antihypertensives, anticancer drugs, and improve the bioavailability of some nutraceuticals $[26,27]$. Due to their natural origin, ease of access, cost-effectiveness and satisfactory safety profiles, these kinds of nutraceuticals have attracted the attention of scientists, consumers, and commercial enterprises [28].

\subsection{Piperine as a Nutraceutical}

Piperine (E,E)-1-piperoylpiperidine or (E,E)-1-[5-(1,3benzodioxol-5-yl)-1-oxo-2,4 pentdienyl]-piperidine is an alkaloid present in the piper species, the fruit of black pepper (Piper nigrum Linn.) and long pepper (Piper longum Linn.). Piperine has been used in traditional medicine for a long time, in treatment of various conditions: rheumatism and muscular aches, as a digestive tonic, in dyspepsia, in flatulence and indigestion, as antipyretic, for throat pain and cough; as antiseptic, bactericide, insecticide, diuretic, etc. [29]. In addition to its traditional use, crucial non-traditional nutraceutical effects have been proposed for piperine, based on cellbased studies, animal studies and human studies, reviewed in several articles [26, 29-36]. For example, piperine increases the bioavailability of several drugs from 30 up to 200 fold; for curcumin, this enhancing ability was almost $9-10$ fold [37, 38].

Piperine is a molecule that is a promising nutraceutical, with some of its potential uses represented in Fig. (1). Moreover, its structure is especially suitable for chemical modifications and al- terations, it can present an advantage in the development of novel compounds with various health protective activities.

\section{CHEMICAL AND PHYSIOLOGICAL CHARACTERIS- TICS OF PIPERINE}

\subsection{Chemistry of Piperine and its Importance for the Com-} pound's Mechanism of Action

The piperine type of amides are a group of alkaloids; their biogenesis is initiated by the pyridoxal-phosphate catalyzed decarboxylation of L-lysine to cadaverine, which undergoes an enzymatic oxidative deamination to amino aldehyde which cyclizes to the imine form $\Delta^{1}$-piperideine, followed by a reduction of piperidine which reacts with piperoil-Co-A (piperic acid-coenzyme A ester) forming a piperine [39].

Piperine, accounting for around $98 \%$ of the total amount of alkaloids in black pepper, is the most abundant pungent alkaloid; it is responsible for the pungency of pepper. Single crystal X-ray diffraction and mass spectroscopic analysis of yellow prism-like crystal revealed a melting point in the range $128-130{ }^{\circ} \mathrm{C}$. The crystal and molecular structure of piperine (1-piperoylpiperidine) has been discovered after recrystallisation from ethanol oleoresin extract of black pepper, i.e. the molecular formula of $\mathrm{C}_{17} \mathrm{H}_{19} \mathrm{O}_{3} \mathrm{~N}$ and a molecular mass of 285.1365 . It has been revealed that piperine is ternary type of amide which is formed between piperidine in the chair conformation and piperic acid (5-(3,4-methylenedioxyphenyl)-2,4-pentadienoic acid) [40].

Four geometric isomers of piperine, represented in Fig. (2), have been characterized: The major component piperine (transtrans isomer), isopiperine (cis-trans isomer), chavicine (cis-cis isomer), and isochavicine (trans-cis isomer), the last three forms do 


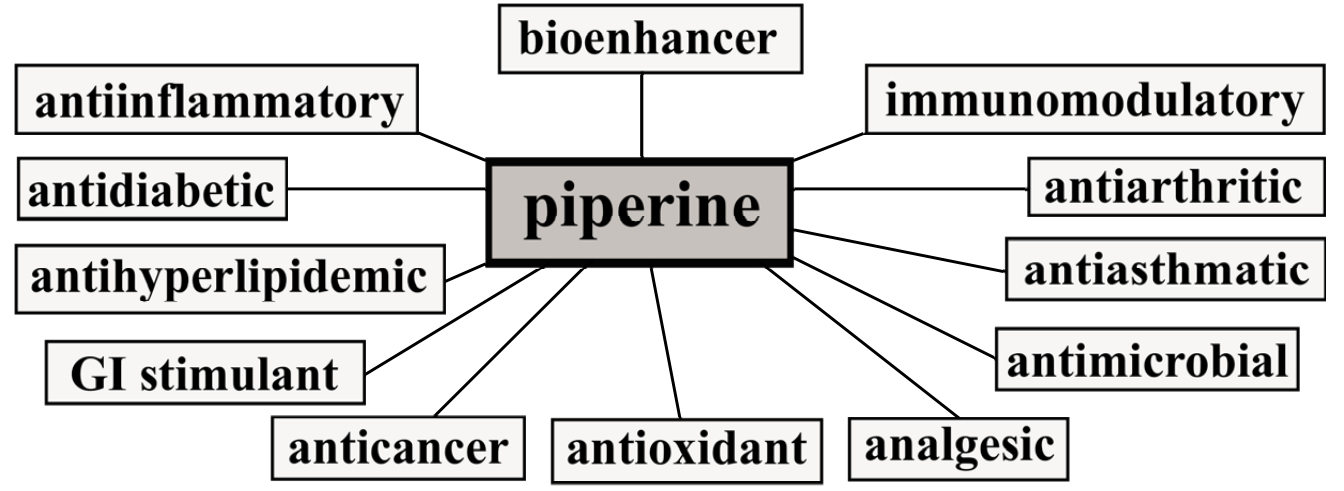

Fig. (1). Potential uses of piperine as nutraceutical.<smiles>CC1Oc2ccc(/C=C/C(=O)N3CCCCC3)cc2O1</smiles>

Piperine<smiles>CC1Oc2ccc(/C=C/C(=O)N3CCCCC3)cc2O1</smiles>

Chavicine<smiles>CC1Oc2ccc(/C=C/C(=O)N3CCCCC3)cc2O1</smiles>

Isopiperine<smiles>CC1Oc2ccc(/C=C/C=C/C(=O)N3CCCCC3)cc2O1</smiles>

Isochavicine

Fig. (2). Geometric isomers of piperine.

not possess any pungent properties [36]. The rate and degree of isomerization are variable. After oral ingestion of piperine in doses of $50 \mathrm{mg}$, no isomers other than piperine were detected in human plasma (healthy volunteers) [41, 42]. Piperine is a weak base that undergoes hydrolysis and has a limited solubility in water (only 40 $\mathrm{mg} / \mathrm{L}$ at $18^{\circ} \mathrm{C}$ ) [43]. This is a challenge, but it may be possible to overcome these limitations with nano-scaled formulations for polyphased delivery systems (e.g. solid dispersions, solutions, capsulated vesicles and particles) as well as advanced energy-efficient and environmentally friendly extraction technologies (e.g. supercritical fluid extraction, ultrasound and microwave- assisted extractions) [36]. The combination of Accelerated Solvent Extraction (ASE) of piperine and its quantification by thin layer chromatography (TLC) has proved to be an efficient, precise, accurate and costfriendly analytical technique for the rapid screening of the quality of these kinds of spices [44].

The production of molecular salts of piperine with highly water soluble counter ions, offers an opportunity for increasing the water solubility of piperine i.e. these modifications affect its absorption rate and enhance its bioavailability. A recent study on non-covalent interactions between piperine and native $\beta$-cyclodextrin underlined the increased water solubility of piperine due to the formation of a piperine- $\beta$-cyclodextrin inclusion complex in solution [45].

The native form of the piperidine molecule inhibits UDPglucose dehydrogenases [46] and specific dehydrogenase complexes associated with the electron transport chain [47]. An assessment of the structure- activity relationship of 38 modified piperine derivatives revealed that the degree of saturation of the unsaturated double bonds in the side chain of the piperidine molecule correlates with enhanced inhibition of rat hepatic constitutive and inducible cytochrome P450 (CYP450) activities. Furthermore, it has been demonstrated that the substituted methylenedioxyphenyl ring and basic piperidine ring contribute to their maximal selectivity [48]. Therefore, these synthetic piperine analogues may be useful in modifying the bioavailability.

Fluorescence titration measurements of two different binding constants of piperine complex with human G-quadruplex DNA sequences correlate to affinity of piperine for two different binding sites. The highest value is a result of the binding of piperine with Pu24T c-myc G-quadruplex DNA as compared to other Gquadruplex DNA i.e. differences in sequences and topology lead to reduced affinity in the specific binding in the formation of piperineDNA complexes [49].

\subsection{Absorption and Metabolism of Piperine}

The findings regarding the absorption and metabolism of piperine in humans have largely originated from animal studies. In one of the first investigations of piperine metabolism, piperine was administered to male albino rats $(170 \mathrm{mg} / \mathrm{kg})$ by gavage and around $97 \%$ was found to be absorbed. Approximately 3\% of the administered dose of piperine was excreted in the feces, while levels in urine were undetectable, indicating its complete metabolic conversion [50]. Piperine was absorbed very rapidly through the intestinal barrier [51]. After intestinal absorption, due to its insolubility in water, serum albumin is proposed to be the main carrier in its transportation in blood [52]. However, in serum only traces of piperine $(<0.15 \%)$ from $30 \mathrm{~min}$ to $24 \mathrm{~h}$ after administration were detected, which implies its very low bioavailability and intensive intestinal 
metabolism. The main routes of Phase II metabolism of piperine are glucuronidation and sulpha-conjugation. After oral administration of piperine (in rats), the following main metabolites were detected in urine, at $0-96 \mathrm{~h}$ after administration: piperonylic acid, piperonyl alcohol, piperonal, and vanillic acid; at 0-6 h after administration, piperic acid could be detected in bile, but no metabolites could be determined in feces $[31,50]$. One human study revealed that after intake of piperine capsules $(20 \mathrm{mg})$ for 7 days, piperine did not accumulate in healthy volunteers [53].

\subsection{Toxicological Data on Piperine}

Piperine can be present in human diet as natural ingredient of black pepper or can be added to food and drink as flavouring agent in different concentrations which can vary extensively, from 0.4-6 ppm (in candies) to $640 \mathrm{ppm}$ (in some baked products) [54]. Regarding the fact that oleoresin of black pepper consists of $40 \%$ piperine, individual human exposure to piperine is estimated based on black pepper consumption and is around $1 \mathrm{pg} / \mathrm{kg} / \mathrm{day}$ [55]. Based on these data, and the fact that piperine is more irritant rather than toxic, its intake from regular food raised no safety concern. No observed adverse effect level (NOAEL) of piperine is $5 \mathrm{mg} / \mathrm{kg}$ daily [56].

The pharmaceutical use of piperine is limited due to its low water solubility of only $40 \mathrm{mg} / \mathrm{L}$ at $18{ }^{\circ} \mathrm{C}$ [43] and putative toxicity (immunotoxicity, reproductive and neurotoxicity) at high concentrations $[57,58]$. The different toxicity aspects of piperine have been evaluated in the past years. $\mathrm{LD}_{50}$ of piperine in mice and rats is estimated to be 330 and $514 \mathrm{mg} / \mathrm{kg}$, respectively. Doses of 100 $\mathrm{mg} / \mathrm{kg}$ were found to be nontoxic in subacute toxicity tests [59]. Piperine has been claimed to be a non-genotoxic chemical based on the results from four different types of genotoxicity tests (Ames test, micronucleus test, test for sperm shape abnormality and dominant lethal test) [60-63]. Furthermore, piperine was observed to exert a suppressive effect on the micronucleus formation induced by benzo $(a)$ pyrene and cyclophosphamide in mice [64, 65]. In addition, there are studies where the antigenotoxic effects of piperine (provided as a feed additive) against the toxicity of aflatoxin $\mathrm{B}_{1}$ have been analyzed and it was proposed as being safe with respect to its protective role against aflatoxin-genotoxic action [66].

The immunotoxicity of piperine has been investigated in Swiss male mice where doses of $1.12,2.25$ or $4.5 \mathrm{mg} / \mathrm{kg}$ were administered [67]; piperine was assessed to be an immunologically safe compound. Furthermore, piperine was found to possess immunomodulatory properties and to confer protection against the immunotoxicity evoked by different agents, for example, cadmium [68, 69], cypermethrin [70] or deltamethrin [71]. In these studies, piperine has been claimed to be an effective agent in reducing the adverse effects of immunotoxins on apoptosis, blastogenesis, T- and B-cell phenotypes differentiation and cytokine production. Piperine contains a pentacyclic oxindole group in its molecule, which might be related to its possible immunomodulatory properties.

With regard to reproductive toxicity, the majority of studies have been conducted on experimental animals, most usually in rats or Swiss albino mice, i.e. a short-term toxicity test was employed for assessing piperine's effects on estrous cycle, spermatogenesis, fertilization, male germ cell, epididymis enzymes, etc. Doses up to $75 \mathrm{mg} / \mathrm{kg}$ did not induce abnormalities, while at higher doses (100 $\mathrm{mg} / \mathrm{kg}$ ) reductions were observed in the activity of enzymes and sialic acid levels in the epididymis as well as in testis development in pubertal rats [72-74].

\section{INTERACTIONS OF PIPERINE WITH OTHER COM- POUNDS}

\subsection{Piperine-drug Interactions}

Beside regular dietary sources, piperine is an ingredient of numerous marketed herbal medicines and food supplements. Excess intake of these products, that provide more than $10 \mathrm{mg}$ of piperine, might result in clinically significant interactions with several drugs [75]. As such, piperine can have a great impact on the bioavailability and pharmacokinetics of other co-administered drugs by modulating their intestinal absorption and metabolism.

There are two possible pathways for nonspecific piperine-drug interactions:

(1) Promoting more efficient absorption of drugs (or some nutrients) by prevention of their non-enzymatic breakdown (decreased secretion of $\mathrm{HCl}$ in the stomach) or promotion of active and passive transport mechanisms in the intestine, and

(2) Interaction mechanisms where piperine inhibits drugmetabolising enzymes thus preventing the drug's inactivation and elimination $[26,33,76]$.

It has been reported that piperine induces alterations in the villus-crypt structure that alter its fluidity as well as evoking changes in the conformation and activity of enzymes on the outer intestinal membrane. Another possibility to explain piperine's bioenhancing properties is that it changes gastric emptying and transit time to allow increased drug absorption [33, 77-80].

Piperine has been shown to inhibit both in vivo and in vitro drug-metabolizing enzymes and drug-transporter proteins in a nonspecific manner [31, 81-84]. However, it has also been observed to exert stimulating effects on the activity/expression of some enzymes (mainly those in the CYP family) depending on the route, dose and time of piperine exposure $[85,86]$. Piperine has been reported to inhibit many important detoxifying enzymes e.g. cytochrome P450 family (mainly CYP3A4, also CYP1A1, CYP 1B1/B2, CYP2E1, etc.), aryl hydrocarbon hydroxylase (AHH), ethyl morphine-N demethylase, 7-ethoxycoumarin-O-de-ethylase, 3-hydroxy- benzo[a]pyrene glucuronidase, uridine diphosphate glucose dehydrogenase (UDP-GDH), uridine diphosphate glucuronyl transferase (UDP-GT), 5-lipoxogenase (5-LOX), cyclooxygenase-I (COX-I). The majority of drugs available today are metabolized by CYP enzymes (e.g., CYP3A4) and UGT, thus studies of possible interactions with piperine have mainly focused on these entities [80, 87, 88].

The inhibitory effects of piperine on the activity and expression of drug-transporter proteins have been investigated mainly with transporters belonging to ATP-binding cassette (ABC) family, like P-glycoprotein (P-gp) [89]. Piperine modulates the activity and expression of $\mathrm{P}$-gp. This interaction is currently a subject of great research interest because of putative alterations of the pharmacokinetic profile and consequent adverse effects of P-gp substrate drugs on one hand, and on the other, the possible beneficial effects in cancer treatment. For example, piperine may enhance the cytotoxicity of anticancer drugs or reverse multidrug resistance in a dosedependent manner [80]. Beside anticancer agents, there are different classes of drugs, which may interact with piperine: carvedilol, diclofenac, fluvastatin, glimepiride, glipizide, ibuprofen, losartan, naproxen, rosiglitazone, valproic acid; all of them are listed in DrugBank database (www.drugbank.ca/drugs/DB12582).

\subsection{Interactions of Piperine with other Nutraceuticals: Focus on Curcumin}

Curcumin is a popular and widely investigated nutraceutical, since it exerts antioxidant, anti-inflammatory, antimicrobial and anticancer effects. However, this natural polyphenol has limited therapeutic potential due to its poor bioavailability i.e. its limited aqueous solubility, poor absorption, extensive metabolism in liver and intestine, as well as its rapid elimination (for a review see Hewlings and Kalman, 2017, [90]). Piperine has been postulated to overcome the pharmacokinetic drawbacks of curcuminoids like curcumin e.g. it was reported to increase its bioavailability up to $2000 \%$ in humans [91]. Piperine enhances the absorption of curcuminoids by reducing the activity of glucuronidase both in intestine 
and the liver, and by increasing intestinal perfusion [91]. There are a number of convincing reports providing clear evidence that coadministration of curcumin with piperine maximizes its antioxidant, anti-inflammatory effects thus conferring protection against a variety of diseases. In a recent double-blind placebo-controlled study in type 2 diabetes patients, co-supplementation of curcumin with piperine (1000 and $10 \mathrm{mg}$ /day respectively) for 8 weeks led to an enhanced antioxidant capacity as reflected in an elevated serum total antioxidant capacity (TAC), increased activity of superoxide dismutase (SOD) and lowered levels of lipid peroxidation [92]. Consistently, in a randomized double-blind placebo-controlled trial in subjects with the metabolic syndrome (MetS), 8-week supplementation of curcumin $(1 \mathrm{~g} /$ day $)$ with piperine $(10 \mathrm{mg}$ /day $)$ decreased lipid peroxidation and induced SOD activity. Furthermore, in the same study, curcumin and piperine co-supplementation exerted an anti-inflammatory effect as evidenced by a decrease in hsCRP; it also improved glucose metabolism as revealed by a decrease in HbA1c levels [93]. Increased oxidative stress and inflammation are emerging components of the pathogenesis of exerciseinduced muscle damage. The protective role of curcumin and piperine against exercise-induced muscle damage was explored recently in elite rugby players. Daily supplementation with $6 \mathrm{~g}$ of curcumin and $60 \mathrm{mg}$ of piperine between $48 \mathrm{~h}$ before and $48 \mathrm{~h}$ after acute exercise partly attenuated markers of muscle damage and soreness [94]. Among the existing strategies to enhance the bioavailability and antioxidant properties of curcumin, co-administration of curcumin and piperine together with quercetin have been claimed to be potentially beneficial. A combination treatment consisting of curcumin with piperine and quercetin was able to combat impaired SOD and glutathione peroxidase activities, and the reduced glutathione levels evoked by consumption of a high-fat diet or streptozotocin-induced diabetes in rats [95]. Nonetheless, in contrast to these reports, treatment of curcumin with $20 \mathrm{mg} / \mathrm{kg}$ piperine to rats with experimentally-induced diabetes did not further improve antidiabetic and antioxidant effects of curcumin; in fact, cosupplementation of piperine at a $40 \mathrm{mg} / \mathrm{kg}$ dose abolished the beneficial effects of curcumin [96].

Synergistic interactions of piperine with other nutraceuticals have been reported [26]. In a recent study, four weeks of cosupplementation of resveratrol with piperine potentiated efficiency of low-intensity exercise training on skeletal muscle mitochondrial capacity in healthy young adults [97]. Similarly, compared to single resveratrol supplementation alone, a co-supplementation with piperine increased the bioavailability of resveratrol by $229 \%$ and decreased its metabolites approximately $80 \%$ [98]. This bioenhancing effect was attributed to inhibiting glucuronidation, and slowing down the elimination of resveratrol by piperine [98]. Moreover, earlier human studies demonstrated that oral supplementation of piperine increased gastrointestinal absorption of beta carotene [99] and elevated plasma levels of co-enzyme Q10 [100].

\section{RECENT THERAPEUTIC INSIGHTS OF PIPERINE AS ANTICANCER AGENT: THE IMPORTANCE OF ANTI- OXIDANT POTENTIAL}

Oxidative stress, a state of imbalance between the generation of reactive oxygen species (ROS) and the antioxidant defense capacity of the organism, is nowadays known to be involved in many disease processes including cancer, but also atherosclerosis, inflammation, ageing, etc. [101-103]. Indeed, high concentrations of ROS are harmful to the organism since they can damage all of the major cellular constituents e.g. evoking lipid-, DNA-, protein oxidation resulting in protein misfolding and aggregation [104]. In contrast, at moderate concentrations, ROS play an important role in cellular signaling and are essential in physiological homeostasis. Therefore, increased ROS production during times of increased oxidative stress can disrupt redox regulation of cellular processes [105]. In biological systems, there is a kind of orchestrated synergism, in which a variety of endogenous and dietary antioxidants detoxifies ROS, to combat oxidative stress and maintain redox control [106].

The health benefits of piperine have been attributed to its possible antioxidant properties and inhibitory effects on the production of ROS (see for a review of Srinivasan, 2014) [107]. Earlier studies demonstrated that piperine was a potent inhibitor of oxidative damage capable of preventing lipid peroxidation in vitro [108]. Furthermore, piperine inhibited copper-induced lipid peroxidation of human low density lipoprotein (LDL) as reflected in a decrease in the level of thiobarbituric acid reactive substance (TBARS) and relative electrophoretic mobility (REM) of LDL on agarose gel [109]. However, at equimolar concentrations, the inhibitory effect of piperine on oxidation of LDL was less potent than the other compounds studied i.e. curcumin, quercetin and capsaicin [109]. Nonetheless, piperine supplementation $(0.02 \mathrm{~g} / \mathrm{kg}$ body weight $)$ for 10 weeks counteracted to a significant extent the increased lipid peroxidation and impaired antioxidant enzyme activities and reduced glutathione (GSH) levels in rats fed a high-fat diet [29]. The protective role of piperine against oxidative stress was confirmed in a recent study, in which piperine at concentrations of 35 and $50 \mu \mathrm{M}$ improved lipid peroxidation and prevented DNA damage in a cadmium-induced model of oxidative stress in peripheral blood lymphocytes obtained from healthy individuals [110].

The impact of low dose and short term piperine treatment $(10$ $\mathrm{mg} / \mathrm{kg} /$ day, intraperitoneally for 14 days) has been investigated in various tissues of rats with streptozotocin-induced diabetes (SID). Treatment with piperine reversed the SID-induced disruptions in oxidative stress and antioxidant defense markers in a tissue-specific manner [111]. Piperine treatment counteracted SID-induced oxidative stress as reflected in the increased oxidized glutathione (GSSG) levels in the brain and the prevention of lipid peroxidation in heart tissue. In addition, piperine supplementation restored the reduced activities of glutathione peroxidase (GSHPx) and SOD in kidney tissue and glutathione reductase in heart tissue. On the other hand, in liver tissue, piperine supplementation did not prevent oxidative stress or reverse the impaired antioxidant defense in SID rats. In fact, it even induced oxidative stress in non-diabetic animals i.e. there was an increase in the glutathione oxidation ratio [111]. In another study employing the rat SID model, the effects of different doses of piperine treatment on oxidative stress and antioxidant markers were compared. Lower doses of piperine supplements (20 $\mathrm{mg} / \mathrm{kg}$ ) for 45 days decreased markers of lipid peroxidation and protein oxidation and conversely increased the activities of three antioxidant enzymes SOD, GSHPx and catalase [96]. Notably lower doses of piperine supplementation enhanced GSH, which is an important endogenous antioxidant and a key redox regulator. Surprisingly, at higher piperine supplementation doses $(40 \mathrm{mg} / \mathrm{kg})$, these beneficial alterations in oxidative stress markers and antioxidant defense were largely abolished in the SID rats [96]. The same pattern of a dose-dependent dual action of piperine was observed in another study, i.e. at lower doses, piperine acted as a hydroxyl radical scavenger, but at higher concentrations, there was evidence of an activated Fenton reaction and increased production of hydroxyl radicals [108]. Nevertheless, a recent study demonstrated that in H661 cells, that have a very low background level of ROS production, piperine treatment between $0.5-100 \mu \mathrm{M}$ concentrations did not induce any ROS generation [112]. In addition, piperine displayed a moderate $\mathrm{H}_{2} \mathrm{O}_{2}$ scavenging effect and a minor inhibition of ROS production as revealed by attenuated NADPH oxidase (NOX) activity [112].

These studies provide evidence that the antioxidant properties of piperine may be dose-dependent and tissue-specific. On the other hand, as far as we are aware, there are no human studies performed that uncover the role of sole supplementation of piperine on antioxidant protection against oxidative stress. Nevertheless, several human studies revealed the bioenhancer role of piperine in combination with other antioxidant compounds [97-100]. Therefore, 
piperine not only possesses antioxidant effects itself, but it can also potentiate the antioxidant effects of other nutraceuticals as summarized in the previous section.

Piperine's confirmed antioxidative effect could well be linked with chemoprevention. According to current theories, piperine could be effective as an anticancer agent, alone, or in combination with other anti-cancer agents. The mechanism of piperine antitumor effect might be related to its immunomodulatory properties [113], but many reports point out the importance of its antioxidant activity as well as its ability to inhibit the proliferation and survival of various types of cancer cells. Other beneficial properties may be modulation of redox homeostasis, induction of detoxification enzymes, inhibition of angiogenesis, and sensitization of tumors to radiotherapy and chemotherapy $[114,115]$.

There are many reports investigating the involvement of piperine in combatting carcinogenesis. The effects of piperine on the procarcinogenesis arising from toxicity and genotoxicity induced by aflatoxin $\mathrm{B}_{1}$ have been investigated for several decades. In an early study, Singh and his collaborators (1994) demonstrated that piperine could reduce the toxicity of aflatoxin $\mathrm{B}_{1}$, suppressing the toxicity (activation) of the mycotoxin via the cytochrome p-450 pathway. This conclusion was achieved using rat hepatoma cells H4IIEC3/G-(H4IIE) and analyzing cellular growth and the formation of micronuclei [116]. Later in 1997, Reen et al. reported that piperine was a potent inhibitor of rat CYP4502B1 activity; this prevented the CYP4502B1-mediated activation of aflatoxin B1 in these cells, i.e. it acted chemopreventive against the procarcinogenesis mediated through this pathway [117]. Subsequently, Selvendiran and collaborators have examined the chemopreventive/anticancer properties of piperine. They investigated the cytoprotective effect of piperine after inducing an experimental lung cancer in male Swiss albino mice, using benzo[a]pyrene, a carcinogen known to cause lipid peroxidation. They monitored the level of lipid peroxidation and the status of several enzymatic antioxidants (SOD, catalase and glutathione peroxidase) and non-enzymatic antioxidants (reduced glutathione, vitamin E, and vitamin C) levels. They reported that piperine, when given by oral route at $100 \mathrm{mg} / \mathrm{kg}$, enhanced the levels of both enzymatic and non-enzymatic antioxidants and suppressed lipid peroxidation not only if the animals were treated with piperine prior to the induction of lung cancer, but also in those receiving piperine after the induction of the lung cancer. Since there was a more pronounced effect in pre-treated animals, it was postulated that piperine exerted chemopreventive effects [118]. In further investigations using the same model, a significant decrease in the levels of lipid peroxidation was observed [119, 120]. These investigators also revealed that levels of protein carbonyls, nucleic acid content and polyamines (i.e. factors known to be increased in lung cancer-bearing animals), were lowered after piperine administration. The ability of piperine to inhibit lung metastasis induced by administration of B16F-10 melanoma cells to C57BL/6 mice was studied by Pradeep and Kuttan (2002). They reported that piperine was $100 \%$ cytotoxic to B16F-10 melanoma cells at a concentration of $100 \mu \mathrm{g} / \mathrm{mL}$, while being nontoxic at a tenfold lower concentration. They also observed a significant reduction in lung tumor nodule formation $(95.2 \%)$ when animals were treated with piperine $(200 \mu \mathrm{mol} / \mathrm{kg}$ body weight/dose) simultaneously with the inoculation of the tumor cells in order to generate a metastatic disease. An increase in the life span of these mice was also noted as an outcome of piperine administration. After analyzing several other parameters, such as lung collagen hydroxyproline, lung uronic acid and hexosamine contents, serum sialic acid and serum gamma glutamyl transpeptidase, they concluded that all these metastasis markers significantly declined in response to piperine administration [121].

Bezeera et al. (2006), examined the potential of piperine and piplartine to inhibit Sarcoma 180 -initiated tumor growth in Swiss mice, comparing their activity with 5-fluorouracil (5-FU) treatment.
A significant reduction in the tumor weight was observed with both administered doses $(50$ and $100 \mathrm{mg} / \mathrm{kg}$ ), in piplartine- and piperinetreated animals; there was a tumor growth inhibition ratio of $55.0 \%$ and $56.8 \%$ for piperine, at doses of 50 and $100 \mathrm{mg} / \mathrm{kg}$, respectively. At a dose of $25 \mathrm{mg} / \mathrm{kg}$ per day, 5-FU was observed to reduce tumor weight by $76.7 \%$, over the same time frame [122]. The same group conducted a more extensive analysis of the effects of piperine and piplartine, but in combination with 5-FU. They undertook an in vitro test of inhibitory activity in four different tumor cell lines, HL-60, MDA-MB435, SF295 and HCT-8. They observed that the piplartine-5- FU combination exerted more potent in vitro cytotoxic effects than piperine-5-FU, although previously both substances were reported to have similar antitumor activities in vivo in the Sarcoma 180 model [123]. The antitumor action and immunomodulatory activities of piperine and alcoholic Piper longum extracts were examined by Sunila and Kuttan (2004). They reported that piperine alone evoked more potent cytotoxicity to Dalton's lymphoma ascites cells than Piper longum alcoholic extract. They also observed an increase in the life span of Ehrlich ascites carcinoma bearing Swiss albino mice. Furthermore, the animals treated with the $1.14 \mathrm{mg}$ intraperitoneal (i.p.) dose of piperine experienced a greater reduction in tumor growth than those receiving the i.p. alcoholic extract of Piper longum at a dose of $10 \mathrm{mg}$ [113].

During the current decade, the potential benefits of piperine have been examined in some detail. Lai et al. (2012), investigated the effects of piperine on tumor growth and metastasis in 4T1 mammary carcinoma in female BALB/c mice. Piperine was injected into the tumor mass every 3 days on 3 occasions. When injected in two doses, 2.5 and $5 \mathrm{mg} / \mathrm{kg}$ piperine showed suppression of primary 4T1 tumor growth in dose-dependent manner. At the same time, administration of $5 \mathrm{mg} / \mathrm{kg}$ piperine was reported to significantly inhibit the lung metastasis [124]. In an attempt to reveal the underlying mechanisms of piperine's action, Hwang and his collaborators examined the effects of piperine at preventing tumor invasion and migration using human fibrosarcoma HT-1080 cells. Their study revealed piperine-mediated suppression of the expression of metalloproteinase-9 (MMP-9) at different levels, suggesting that piperine could possibly inhibit tumorigenesis [125]. The antitumor properties of piperine have also been investigated in breast cancer cells by Do et al., (2013). They observed that piperine induced growth inhibition and cytotoxicity through both caspase-3 activation and PARP cleavage in several types of human breast cancer cells that were overexpressing HER2. The authors also confirmed the existence of the suppression of EGF-induced MMP-9 expression. In addition, pretreatment with piperine enhanced the sensitization of HER2-overexpressing breast cancer cells to paclitaxel-induced growth inhibition and apoptosis [126].

Further insights into the mechanism of action of piperine have revealed that it can bind to various human G- quadruplex DNA sequences. Tawani and collaborators reported that piperine's anticancer activity could be mediated through the stabilization of the Gquadruplex structure formed at the c-myc promoter region of the DNA sequence (Pu24T), leading to a down-regulation of its expression in cancer cells [49]; this might be the mechanism behind piperine's anticancer activities observed in the above mentioned studies.

\section{CURRENT DEVELOPMENTS AND FUTURE PERSPEC- TIVES}

It is of no doubt that the antioxidative effect is the most exploited and most important property of piperine, especially concerning its anticancer activity. However, recent research reveal that also the prooxidant activity of piperine, affecting redox state of cancer cells, might be relevant to its anticancer potential [127]. Namely, the increased oxidative stress results in extreme susceptibility of cancer cells to prooxidant agents that eventually make piperine selectively cytotoxic [115]. 
A number of investigations have been and still are being performed with a primary goal of defining the biological activities and possible health risks of black pepper and its active principle, piperine. Clinical trials that include sole use of piperine in human subjects are still missing. Nevertheless, evidences from animal studies support its non-toxicity if administered in moderate doses [128, 129].

The main issues that today still limit the wider use of piperine in medical practice, specifically in combination therapy to exploit its bio-enhancer properties, are related to its low bioavailability and potential for drug interactions. These problems still need to be resolved and attention must be paid to the proper dose and dosing regimen, as well as to the design of suitable pharmaceutical formulation(s) that will improve piperine's in vivo effects. Currently, the major efforts to transfer piperine from basic research to clinical practice are focused on the development of formulations that improve its low aqueous solubility and poor absorption. For example, one development has been the encapsulation of piperine in lipid carriers (e.g., liposomes), or its incorporation in nanoparticles [130137].

Even though its mechanism of action has not been completely clarified, piperine is established as the first certified bioenhancer due to its ability to reduce the activity of certain enzymes (mainly CYP3A4) and to inhibit P-gp. In this respect, currently its main application in pharmaceutical formulations is as a bioavailability enhancer for different drugs and natural compounds in complex delivery systems. Combinations of piperine and drugs used to treat several major diseases, including tuberculosis, cardiovascular, neurological, and gastrointestinal disorders, are being evaluated (www.drugbank.ca/drugs/DB12582). Since nowadays plant extracts are preferred as active agents, trials are being performed with novel formulations of drug delivery systems loaded with these components [138]. For example, Hoffman et al., (2014) have devised pronanolipospheres (PNLs) which consist of orally administrable combinations of lipids, surfactants and co-solvent loaded with piperine [139]. This kind of system would improve the bioavailability of drugs with poor pharmacokinetic properties i.e. achieving a reliable absorption of the drug from the GI tract. In the future, other drugs and herbal extracts encumbered by poor intestinal absorption due either to their low permeability or the fact that they are Pglycoprotein substrates may be formulated with piperine i.e. piperine can inhibit intestinal P-gp and thus facilitate the drug's absorption. As an example, researchers recently developed a formulation to allow the oral delivery of drugs or herbal extracts with low solubility/permeability after their complexation with piperine in a carbohydrate substrate solubilized with water, ethanol or an organic solvent [140]. This solution was water soluble and not a substrate of P-gp. Moreover, in the most recent studies, piperine has been used as a penetration enhancer, i.e. it elevated the flux rate of an active compound (capsaicin) in a transdermal delivery device [141].

These promising results from the nano-formulations of piperine highlight the possibility that new drug delivery systems will become available and piperine's putative health benefits may be fully exploited.

\section{CONCLUSION}

Today, there is no doubt that piperine, the most abundant component in species of pepper, possesses optimal characteristics for inclusion into the broad nutraceutical family. Many studies have not only confirmed its antioxidant but also bioavailability enhancer properties for other antioxidants. As research on this topic continue to expand, new opportunities are opening. Progress is made in achieving a deeper understanding of piperine's action, as well as in finding new ways to improve its bioavailability by incorporation into different carrier systems, mostly of a nano-sized nature. In conclusion, the interest in this compound is being redirected, it is no longer simply an interesting component from a well-known pungent spice, and instead, it should be considered as a new and important nutraceutical.

\section{CONSENT FOR PUBLICATION}

Not applicable.

\section{FUNDING}

None.

\section{CONFLICT OF INTEREST}

The authors declare no conflict of interest, financial or otherwise.

\section{ACKNOWLEDGEMENTS}

This work is a part of the activities within the frames of COST action CA16112, titled "Personalized Nutrition in aging society: redox control of major age-related diseases" (NutRedOx). The authors gratefully acknowledge Dr. Ewen MacDonald for the language revision.

\section{REFERENCES}

[1] Wildman REC, Kelley M. Nutraceuticals and Functional Foods.Handbook of Nutraceuticals and Functional Foods 2nd ed. 2007; 1-21.

[2] Santini A, Tenore GC, Novellino E. Nutraceuticals: A paradigm of proactive medicine. Eur J Pharm Sci 2017; 96: 53-61. [http://dx.doi.org/10.1016/j.ejps.2016.09.003] [PMID: 27613382]

[3] Sharma M, Pankaj D, Ajay R, Anil D. Nutrition nutraceuticals: A proactive approach for health care.Nutraceuticals: Nanotechnology in the Food Industry 2006; Vol. 4: 79-116.

[4] Arai S. Studies on functional foods in Japan--state of the art. Biosci Biotechnol Biochem 1996; 60(1): 9-15. [http://dx.doi.org/10.1271/bbb.60.9] [PMID: 8824819]

[5] Diplock AT, Aggett PJ, Ashwell M, Bornet F, Fern EB, Roberfroid MB. Scientific concepts of functional foods in Europe. Consensus document. Br J Nutr 1999; 81(Suppl. 1): S1-S27.

[http://dx.doi.org/10.1017/S0007114599000471] 10999022]

[6] Koch A, Brandenburger S, Türpe S, Birringer M. The need for a legal distinction of nutraceuticals. Food Nutr Sci 2014; 5: 905-13. [http://dx.doi.org/10.4236/fns.2014.510100]

[7] Brower V. Nutraceuticals: Poised for a healthy slice of the healthcare market? Nat Biotechnol 1998; 16(8): 728-31. [http://dx.doi.org/10.1038/nbt0898-728] [PMID: 9702769]

[8] Aronson JK. Defining 'nutraceuticals': Neither nutritious nor pharmaceutical. Br J Clin Pharmacol 2017; 83(1): 8-19. [http://dx.doi.org/10.1111/bcp.12935] [PMID: 26991455]

[9] Sharif MK, Khalid R. Nutraceuticals: Myths Versus Realities. In: Holban AM, Grumezescu AM, Eds. Therapeutic Foods 2018; 3-21.

[10] Zeisel SH. Regulation of "nutraceuticals". Science 1999; 285(5435): 1853-5.

[http://dx.doi.org/10.1126/science.285.5435.1853]

[PMID: 10515789]

[11] Hathcock J. Dietary supplements: How they are used and regulated. J Nutr 2001; 131(3s): 1114S-7S. [http://dx.doi.org/10.1093/jn/131.3.1114S] [PMID: 11238828]

[12] Nicoletti M. Nutraceuticals and botanicals: Overview and perspectives. Int J Food Sci Nutr 2012; 63(Suppl. 1): 2-6.

[http://dx.doi.org/10.3109/09637486.2011.628012]

[PMID: 22360273]

[13] Allen LV. Nutritional Products.Handbook of Nonprescription Drugs 1997.

[14] Gupta S, Chauhan D, Mehla K, Sood P, Nair A. An overview of nutraceuticals: Current scenario. J Basic Clin Pharm 2010; 1(2): 55-62.

[PMID: 24825966]

[15] da Costa JP. A current look at nutraceuticals - Key concepts and future prospects. Trends Food Sci Technol 2017; 62: 68-78. [http://dx.doi.org/10.1016/j.tifs.2017.02.010]

[16] McClements DJ, Li F, Xiao H. The Nutraceutical bioavailability classification scheme: Classifying nutraceuticals according to factors limiting their oral bioavailability. Annu Rev Food Sci Technol 2015; 6: 299-327. 
[http://dx.doi.org/10.1146/annurev-food-032814-014043] [PMID: 25705933]

[17] Pandey M, Verma RK, Saraf SA. Nutraceuticals: New era of medicine and health. Asian J Pharm Clin Res 2010; 3: 11-5.

[18] Catinean A, Neag MA, Muntean DM, Bocsan IC, Buzoianu AD. An overview on the interplay between nutraceuticals and gut microbiota. PeerJ 2018; 6: e4465.

[http://dx.doi.org/10.7717/peerj.4465] [PMID: 29576949]

[19] Santini A, Cammarata SM, Capone G, et al. Nutraceuticals: Opening the debate for a regulatory framework. Br J Clin Pharmacol 2018; 84(4): 659-72.

[http://dx.doi.org/10.1111/bcp.13496] [PMID: 29433155]

[20] Kurian A. Health benefits of herbs and spices.Handbook of Herbs and Spices 2nd ed. 2012; 72-88.

[http://dx.doi.org/10.1533/9780857095688.72]

[21] Hussain SA, Panjagari NR, Singh RR, Patil GR. Potential herbs and herbal nutraceuticals: Food applications and their interactions with food components. Crit Rev Food Sci Nutr 2015; 55(1): 94122

[http://dx.doi.org/10.1080/10408398.2011.649148] [PMID: 24915396]

[22] Gul K, Singh AK, Jabeen R. Nutraceuticals and functional foods: The foods for the future world. Crit Rev Food Sci Nutr 2016; 56(16): 2617-27

[http://dx.doi.org/10.1080/10408398.2014.903384] [PMID: 25629711]

[23] Yashin A, Yashin Y, Xia X, Nemzer B. Antioxidant activity of spices and their impact on human health: A review. Antioxidants 2017; 6(3): 70 .

[http://dx.doi.org/10.3390/antiox6030070] [PMID: 28914764]

[24] Mao XY, Jin MZ, Chen JF, Zhou HH, Jin WL. Live or let die: Neuroprotective and anti-cancer effects of nutraceutical antioxidants. Pharmacol Ther 2018; 183: 137-51

[http://dx.doi.org/10.1016/j.pharmthera.2017.10.012] [PMID: 29055715]

[25] Adefegha SA. Functional foods and nutraceuticals as dietary intervention in chronic diseases; Novel perspectives for health promotion and disease prevention. J Diet Suppl 2018; 15(6): 977-1009. [http://dx.doi.org/10.1080/19390211.2017.1401573] [PMID: 29281341]

[26] Dudhatra GB, Mody SK, Awale MM, et al. A comprehensive review on pharmacotherapeutics of herbal bioenhancers. ScientificWorldJournal 2012; 2012: 637953

[http://dx.doi.org/10.1100/2012/637953] [PMID: 23028251]

[27] Ajazuddin AA, Alexander A, Qureshi A, et al. Role of herbal bioactives as a potential bioavailability enhancer for Active Pharmaceutical Ingredients. Fitoterapia 2014; 97: 1-14.

[http://dx.doi.org/10.1016/j.fitote.2014.05.005] [PMID: 24862064]

[28] Gupta RC, Srivastava A, Lall R. Toxicity potential of nutraceuticals. Methods Mol Biol 2018; 1800: 367-94.

[http://dx.doi.org/10.1007/978-1-4939-7899-1_18] [PMID: 29934903]

[29] Meghwal M, Goswami TK. Piper nigrum and piperine: An update. Phytother Res 2013; 27(8): 1121-30.

[http://dx.doi.org/10.1002/ptr.4972] [PMID: 23625885]

[30] Vijayakumar RS, Surya D, Senthilkumar R, Nalini N. Hypolipidemic effect of black pepper (Piper nigrum Linn.) in rats fed high fat diet. J Clin Biochem Nutr 2002; 32: 31-42.

[http://dx.doi.org/10.3164/jcbn.32.31]

[31] Darshan S, Doreswamy R. Patented antiinflammatory plant drug development from traditional medicine. Phytother Res 2004; 18(5): 343-57.

[http://dx.doi.org/10.1002/ptr.1475] [PMID: 15173991]

[32] Srinivasan K. Black pepper and its pungent principle-piperine: A review of diverse physiological effects. Crit Rev Food Sci Nutr 2007; 47(8): 735-48.

[http://dx.doi.org/10.1080/10408390601062054] [PMID: 17987447]

[33] Chonpathompikunlert P, Wattanathorn J, Muchimapura S. Piperine, the main alkaloid of Thai black pepper, protects against neurodegeneration and cognitive impairment in animal model of cognitive deficit like condition of Alzheimer's disease. Food Chem Toxicol 2010; 48(3): 798-802.

[http://dx.doi.org/10.1016/j.fct.2009.12.009] [PMID: 20034530]
[34] Han H-K. The effects of black pepper on the intestinal absorption and hepatic metabolism of drugs. Expert Opin Drug Metab Toxicol 2011; 7(6): 721-9.

[http://dx.doi.org/10.1517/17425255.2011.570332] [PMID: 21434835]

[35] Umar S, Golam Sarwar AH, Umar K, et al. Piperine ameliorates oxidative stress, inflammation and histological outcome in collagen induced arthritis. Cell Immunol 2013; 284(1-2): 51-9.

[http://dx.doi.org/10.1016/j.cellimm.2013.07.004] 23921080]

[36] Gorgani L, Mohammadi M, Najafpour GD, Nikzad M. Piperine the bioactive compound of black pepper: From isolation to medicinal formulations. Compr Rev Food Sci Food Saf 2017; 16: 124-40. [http://dx.doi.org/10.1111/1541-4337.12246]

[37] Shaikh J, Ankola DD, Beniwal V, Singh D, Kumar MN. Nanoparticle encapsulation improves oral bioavailability of curcumin by at least 9-fold when compared to curcumin administered with piperine as absorption enhancer. Eur J Pharm Sci 2009; 37(3-4): 223-30. [http://dx.doi.org/10.1016/j.ejps.2009.02.019] [PMID: 19491009]

[38] Kesarwani K, Gupta R, Mukerjee A. Bioavailability enhancers of herbal origin: An overview. Asian Pac J Trop Biomed 2013; 3(4): 253-66.

[http://dx.doi.org/10.1016/S2221-1691(13)60060-X] [PMID: 23620848]

[39] Okwute SK, Egharevba HO. Piperine-Type Amides: Review of the Chemical and Biological Characteristics. Int J Chem 2013; 5: 99122.

[http://dx.doi.org/10.5539/ijc.v5n3p99]

[40] Grynpas M, Lindley FP. The crystal and molecular structure of 1piperoylpiperidine. Acta Crystallogr B Struct Sci Cryst Eng Mater 1975; 31: 2663-7.

[http://dx.doi.org/10.1107/S0567740875008412]

[41] Kakarala M, Dubey SK, Tarnowski M, et al. Ultra-low flow liquid chromatography assay with ultraviolet (UV) detection for piperine quantitation in human plasma. J Agric Food Chem 2010; 58(11): 6594-9.

[http://dx.doi.org/10.1021/jf100657r] [PMID: 20465211]

[42] Chavarria D, Silva T, Magalhães e Silva D, Remião F, Borges F. Lessons from black pepper: Piperine and derivatives thereof. Expert Opin Ther Pat 2016; 26(2): 245-64

[http://dx.doi.org/10.1517/13543776.2016.1118057]

[PMID: 26560940]

[43] Vasavirama K, Upender M. Piperine: A valuable alkaloid from piper species. Int J Pharm Pharm Sci 2014; 6: 34-8.

[44] De Mey E, De Maere H, Dewulf L, et al. Application of accelerated solvent extraction (ASE) and thin layer chromatography (TLC) to determination of piperine in commercial samples of pepper (Piper nigrum L.). J Liq Chromatogr Relat Technol 2014; 37: 2980-8. [http://dx.doi.org/10.1080/10739149.2014.907014]

[45] Ezawa T, Inoue Y, Tunvichien S, Suzuki R, Kanamoto I. Changes in the physicochemical properties of piperine/ $\beta$-cyclodextrin due to the formation of inclusion complexes. Int J Med Chem 2016; 2016: 8723139.

[PMID: 8723139]

[46] Reen RK, Jamwal DS, Taneja SC, et al. Impairment of UDPglucose dehydrogenase and glucuronidation activities in liver and small intestine of rat and guinea pig in vitro by piperine. Biochem Pharmacol 1993; 46(2): 229-38.

[http://dx.doi.org/10.1016/0006-2952(93)90408-O] 8347144]

[47] Jamwal DS, Singh J. Effects of piperine on enzyme activities and bioenergetic functions in isolated rat liver mitochondria and hepatocytes. J Biochem Toxicol 1993; 8(4): 167-74.

[http://dx.doi.org/10.1002/jbt.2570080402] [PMID: 8114060]

[48] Koul S, Koul JL, Taneja SC, et al. Structure-activity relationship of piperine and its synthetic analogues for their inhibitory potentials of rat hepatic microsomal constitutive and inducible cytochrome P450 activities. Bioorg Med Chem 2000; 8(1): 251-68. [http://dx.doi.org/10.1016/S0968-0896(99)00273-4] 10968285]

[49] Tawani A, Amanullah A, Mishra A, Kumar A. Evidences for Piperine inhibiting cancer by targeting human G-quadruplex DNA sequences. Sci Rep 2016; 6: 39239.

[http://dx.doi.org/10.1038/srep39239] [PMID: 27995955] 
[50] Bhat BG, Chandrasekhara N. Studies on the metabolism of piperine: Absorption, tissue distribution and excretion of urinary conjugates in rats. Toxicology 1986; 40(1): 83-92.

[http://dx.doi.org/10.1016/0300-483X(86)90048-X]

[PMID: 3715893]

[51] Khajuria A, Thusu N, Zutshi U, Bedi KL. Piperine modulation of carcinogen induced oxidative stress in intestinal mucosa. Mol Cell Biochem 1998; 189(1-2): 113-8. [http://dx.doi.org/10.1023/A:1006877614411] [PMID: 9879661]

[52] Suresh DV, Mahesha HG, Rao AGA, Srinivasan K. Binding of bioactive phytochemical piperine with human serum albumin: A spectrofluorometric study. Biopolymers 2007; 86(4): 265-75. [http://dx.doi.org/10.1002/bip.20735] [PMID: 17407131]

[53] Wang X, Peng W, Zhang Q, et al. Pharmacokinetics of piperine capsules in healthy volunteers. Zhongnan Yaoxue 2010; 8: 513-6.

[54] 2017.https://www.accessdata.fda.gov/scripts/cdrh/cfdocs/cfcfr/ CFRSearch. cfm?FR $=172.515$

[55] Burdock GA. Fenaroli's handbook of flavor ingredients 6th ed.. 2010.

[56] Scientific Opinion on Flavouring Group Evaluation 86, Revision 2 (FGE.86Rev2): Consideration of aliphatic and arylalkyl amines and amides evaluated by JECFA. EFSA J 2015; 13: 3998.

[http://dx.doi.org/10.2903/j.efsa.2015.3998]

[57] Veerareddy PR, Vobalaboina V, Nahid A. Formulation and evaluation of oil-in-water emulsions of piperine in visceral leishmaniasis. Pharmazie 2004; 59(3): 194-7. [PMID: 15074591]

[58] Pachauri M, Gupta ED, Ghosh PC. Piperine loaded PEG-PLGA nanoparticles: Preparation, characterization, and targeted delivery for adjuvant breast cancer chemotherapy. J Drug Deliv Sci Technol 2015; 29: 269-82.

[http://dx.doi.org/10.1016/j.jddst.2015.08.009]

[59] Piyachaturawat P, Glinsukon T, Toskulkao C. Acute and subacute toxicity of piperine in mice, rats and hamsters. Toxicol Lett 1983; 16(3-4): 351-9.

[http://dx.doi.org/10.1016/0378-4274(83)90198-4] [PMID: 6857729]

[60] Karekar VR, Mujumdar AM, Joshi SS, Dhuley J, Shinde SL, Ghaskadbi S. Assessment of genotoxic effect of piperine using Salmonella typhimurium and somatic and somatic and germ cells of Swiss albino mice. Arzneimittelforschung 1996; 46(10): 972-5. [PMID: 8931891]

[61] El Hamss R, Idaomar M, Alonso-Moraga A, Muñoz Serrano A. Antimutagenic properties of bell and black peppers. Food Chem Toxicol 2003; 41(1): 41-7.

[http://dx.doi.org/10.1016/S0278-6915(02)00216-8] [PMID: 12453727]

[62] Thiel A, Buskens C, Woehrle T, et al. Black pepper constituent piperine: Genotoxicity studies in vitro and in vivo. Food Chem Toxicol 2014; 66: 350-7.

[http://dx.doi.org/10.1016/j.fct.2014.01.056] [PMID: 24525095]

[63] Sponchiado G, Adam ML, Silva CD, et al. Quantitative genotoxicity assays for analysis of medicinal plants: A systematic review. J Ethnopharmacol 2016; 178: 289-96.

[http://dx.doi.org/10.1016/j.jep.2015.10.026] [PMID: 26680588]

[64] Selvendiran K, Padmavathi R, Magesh V, Sakthisekaran D. Preliminary study on inhibition of genotoxicity by piperine in mice. Fitoterapia 2005; 76(3-4): 296-300.

[http://dx.doi.org/10.1016/j.fitote.2005.03.016] [PMID: 15890459]

[65] Selvendiran K, Prince Vijeya Singh J, Sakthisekaran D. In vivo effect of piperine on serum and tissue glycoprotein levels in benzo(a)pyrene induced lung carcinogenesis in Swiss albino mice. Pulm Pharmacol Ther 2006; 19(2): 107-11.

[http://dx.doi.org/10.1016/j.pupt.2005.04.002] [PMID: 15975841]

[66] da Silva Cardoso V, Vermelho AB, Ribeiro de Lima CA, et al. Antigenotoxic effect of piperine in broiler chickens intoxicated with Aflatoxin B1. Toxins (Basel) 2016; 8(11): 316.

[http://dx.doi.org/10.3390/toxins8110316] [PMID: 27809242]

[67] Dogra RK, Khanna S, Shanker R. Immunotoxicological effects of piperine in mice. Toxicology 2004; 196(3): 229-36.

[http://dx.doi.org/10.1016/j.tox.2003.10.006] [PMID: 15036749]

[68] Pathak N, Khandelwal S. Cytoprotective and immunomodulating properties of piperine on murine splenocytes: An in vitro study. Eur J Pharmacol 2007; 576(1-3): 160-70.

[http://dx.doi.org/10.1016/j.ejphar.2007.07.033]

[PMID:
[69] Pathak N, Khandelwal S. Comparative efficacy of piperine, curcumin and picroliv against $\mathrm{Cd}$ immunotoxicity in mice. Biometals 2008; 21(6): 649-61.

[http://dx.doi.org/10.1007/s10534-008-9150-y] [PMID: 18566892]

[70] Sankar P, Ramya K. Protective effects of piperine on cypermethrininduced haematological toxicity in rats. Int J Sci Environ Technol 2017; 6: 2971-4.

[71] Kumar A, Sasmal D, Sharma N. Immunomodulatory role of piperine in deltamethrin induced thymic apoptosis and altered immune functions. Environ Toxicol Pharmacol 2015; 39(2): 504-14. [http://dx.doi.org/10.1016/j.etap.2014.12.021] [PMID: 25682002]

[72] Daware MB, Mujumdar AM, Ghaskadbi S. Reproductive toxicity of piperine in Swiss albino mice. Planta Med 2000; 66(3): 231-6. [http://dx.doi.org/10.1055/s-2000-8560] [PMID: 10821048]

[73] D'cruz SC, Mathur PP. Effect of piperine on the epididymis of adult male rats. Asian J Androl 2005; 7(4): 363-8.

[http://dx.doi.org/10.1111/j.1745-7262.2005.00059.x] [PMID: 16281082]

[74] Chen X, Ge F, Liu J, et al. Diverged effects of piperine on testicular development: Stimulating Leydig cell development but inhibiting spermatogenesis in rats. Front Pharmacol 2018; 9: 244. [http://dx.doi.org/10.3389/fphar.2018.00244] [PMID: 29643806]

[75] Gurley BJ, Fifer EK, Gardner Z. Pharmacokinetic herb-drug interactions (part 2): Drug interactions involving popular botanical dietary supplements and their clinical relevance. Planta Med 2012; 78(13): $1490-514$.

[http://dx.doi.org/10.1055/s-0031-1298331] [PMID: 22565299]

[76] Majeed M, Badmaev V, Rajendran R. inventors; Sabinsa Corporation, asignee Use of piperine as a bioavailability enhancer. United States patent US 57441611998 Apr;

[77] Izzo AA, Capasso R, Pinto L, Di Carlo G, Mascolo N, Capasso F Effect of vanilloid drugs on gastrointestinal transit in mice. Br J Pharmacol 2001; 132(7): 1411-6.

[http://dx.doi.org/10.1038/sj.bjp.0703975] [PMID: 11264233]

[78] Sharma P, Varma MV, Chawla HP, Panchagnula R. In situ and in vivo efficacy of peroral absorption enhancers in rats and correlation to in vitro mechanistic studies. Farmaco 2005; 60(11-12): 874-83.

[http://dx.doi.org/10.1016/j.farmac.2005.08.007]

[PMID: 16243320]

[79] Prakash UN, Srinivasan K. Beneficial influence of dietary spices on the ultrastructure and fluidity of the intestinal brush border in rats. Br J Nutr 2010; 104(1): 31-9.

[http://dx.doi.org/10.1017/S0007114510000334] 20178671]

[80] Lee SH, Kim HY, Back SY, Han H-K. Piperine-mediated drug interactions and formulation strategy for piperine: Recent advances and future perspectives. Expert Opin Drug Metab Toxicol 2018; 14(1): 43-57.

[http://dx.doi.org/10.1080/17425255.2018.1418854] 29250980]

[81] Bhardwaj RK, Glaeser H, Becquemont L, Klotz U, Gupta SK, Fromm MF. Piperine, a major constituent of black pepper, inhibits human P-glycoprotein and CYP3A4. J Pharmacol Exp Ther 2002; 302(2): 645-50.

[http://dx.doi.org/10.1124/jpet.102.034728] [PMID: 12130727]

[82] Han Y, Chin Tan TM, Lim LY. In vitro and in vivo evaluation of the effects of piperine on P-gp function and expression. Toxicol Appl Pharmacol 2008; 230(3): 283-9.

[http://dx.doi.org/10.1016/j.taap.2008.02.026] [PMID: 18417181]

[83] Zhang W, Han Y, Lim SL, Lim LY. Dietary regulation of P-gp function and expression. Expert Opin Drug Metab Toxicol 2009; 5(7): 789-801.

[http://dx.doi.org/10.1517/17425250902997967]

[PMID: 19545213]

[84] Jhanwar B, Gupta SS. Biopotentiation using herbs: Novel technique for poor bioavailable drugs. Int J Pharm Tech Res 2014; 6: 443-54.

[85] Dalvi RR, Dalvi PS. Comparison of the effects of piperine administered intragastrically and intraperitoneally on the liver and liver mixed-function oxidases in rats. Drug Metabol Drug Interact 1991; 9(1): 23-30.

[http://dx.doi.org/10.1515/DMDI.1991.9.1.23] [PMID: 1893751]

[86] Singh A, Rao AR. Evaluation of the modulatory influence of black pepper (Piper nigrum, L.) on the hepatic detoxication system. Cancer Lett 1993; 72(1-2): 5-9. 
[http://dx.doi.org/10.1016/0304-3835(93)90003-R]

[PMID: 8402574]

[87] Sevrioukova IF, Poulos TL. Understanding the mechanism of cytochrome P450 3A4: Recent advances and remaining problems. Dalton Trans 2013; 42(9): 3116-26.

[http://dx.doi.org/10.1039/C2DT31833D] [PMID: 23018626]

[88] Oda S, Fukami T, Yokoi T, Nakajima M. A comprehensive review of UDP-glucuronosyltransferase and esterases for drug development. Drug Metab Pharmacokinet 2015; 30(1): 30-51.

[http://dx.doi.org/10.1016/j.dmpk.2014.12.001] [PMID: 25760529]

[89] Bedada SK, Boga PK. The influence of piperine on the pharmacokinetics of fexofenadine, a P-glycoprotein substrate, in healthy volunteers. Eur J Clin Pharmacol 2017; 73(3): 343-9.

[http://dx.doi.org/10.1007/s00228-016-2173-3] [PMID: 27981349]

[90] Hewlings SJ, Kalman DS. Curcumin: A Review of Its' Effects on Human Health. Foods 2017; 6(10): 92.

[http://dx.doi.org/10.3390/foods6100092] [PMID: 29065496]

[91] Shoba G, Joy D, Joseph T, Majeed M, Rajendran R, Srinivas PS. Influence of piperine on the pharmacokinetics of curcumin in animals and human volunteers. Planta Med 1998; 64(4): 353-6. [http://dx.doi.org/10.1055/s-2006-957450] [PMID: 9619120]

[92] Panahi Y, Khalili N, Sahebi E, et al. Antioxidant effects of curcuminoids in patients with type 2 diabetes mellitus: A randomized controlled trial. Inflammopharmacology 2017; 25(1): 25-31. [http://dx.doi.org/10.1007/s10787-016-0301-4] [PMID: 27928704]

[93] Panahi Y, Hosseini MS, Khalili N, Naimi E, Majeed M, Sahebkar A. Antioxidant and anti-inflammatory effects of curcuminoidpiperine combination in subjects with metabolic syndrome: A randomized controlled trial and an updated meta-analysis. Clin Nutr 2015; 34(6): 1101-8

[http://dx.doi.org/10.1016/j.clnu.2014.12.019] [PMID: 25618800]

[94] Delecroix B, Abaïdia AE, Leduc C, Dawson B, Dupont G. Curcumin and Piperine Supplementation and Recovery Following Exercise Induced Muscle Damage: A Randomized Controlled Trial. J Sports Sci Med 2017; 16(1): 147-53.

[PMID: 28344463]

[95] Kaur G, C M. Amelioration of obesity, glucose intolerance, and oxidative stress in high-fat diet and low-dose streptozotocininduced diabetic rats by combination consisting of "curcumin with piperine and quercetin". ISRN Pharmacol 2012; 2012: 957283. [http://dx.doi.org/10.5402/2012/957283] [PMID: 22474599]

[96] Arcaro CA, Gutierres VO, Assis RP, et al. Piperine, a natural bioenhancer, nullifies the antidiabetic and antioxidant activities of curcumin in streptozotocin-diabetic rats. PLoS One 2014; 9(12): e113993.

[http://dx.doi.org/10.1371/journal.pone.0113993]

[PMID: 25469699

[97] Polley KR, Jenkins N, O’Connor P, McCully K. Influence of exercise training with resveratrol supplementation on skeletal muscle mitochondrial capacity. Appl Physiol Nutr Metab 2016; 41(1): 2632

[http://dx.doi.org/10.1139/apnm-2015-0370] [PMID: 26638911]

[98] Johnson JJ, Nihal M, Siddiqui IA, et al. Enhancing the bioavailability of resveratrol by combining it with piperine. Mol Nutr Food Res 2011; 55(8): 1169-76.

[http://dx.doi.org/10.1002/mnfr.201100117] [PMID: 21714124]

[99] Badmaev V, Majeed M, Edward PN. Piperine, an alkaloid derived from black pepper, increases serum response of beta-carotene during 14 days of oral beta-carotenesupplementation. Nutr Res 1999; 19: 381-8. [http://dx.doi.org/10.1016/S0271-5317(99)00007-X]

[100] Badmaev V, Majeed M, Prakash L. Piperine derived from black pepper increases the plasma levels of coenzyme Q10 following oral supplementation. J Nutr Biochem 2000; 11(2): 109-13. [http://dx.doi.org/10.1016/S0955-2863(99)00074-1] 10715596]

[101] Pelicano H, Carney D, Huang P. ROS stress in cancer cells and therapeutic implications. Drug Resist Updat 2004; 7(2): 97-110. [http://dx.doi.org/10.1016/j.drup.2004.01.004] [PMID: 15158766]

[102] Waris G, Ahsan H. Reactive oxygen species: Role in the development of cancer and various chronic conditions. J Carcinog 2006; 5: 14.

[http://dx.doi.org/10.1186/1477-3163-5-14] [PMID: 16689993]

[103] Belaya I, Suwa M, Chen T, et al. Long-Term Exercise Protects against Cellular Stresses in Aged Mice. Oxid Med Cell Longev 2018; 2018: 2894247. [http://dx.doi.org/10.1155/2018/2894247] [PMID: 29765493]

[104] Hulmi JJ, Isola V, Suonpää M, et al. The Effects of Intensive Weight Reduction on Body Composition and Serum Hormones in Female Fitness Competitors. Front Physiol 2017; 7: 689.

[http://dx.doi.org/10.3389/fphys.2016.00689] [PMID: 28119632]

[105] Radak Z, Zhao Z, Koltai E, Ohno H, Atalay M. Oxygen consumption and usage during physical exercise: The balance between oxidative stress and ROS-dependent adaptive signaling. Antioxid Redox Signal 2013; 18(10): 1208-46.

[http://dx.doi.org/10.1089/ars.2011.4498] [PMID: 22978553]

[106] Atalay M, Lappalainen J, Sen CK. Dietary antioxidants for the athlete. Curr Sports Med Rep 2006; 5(4): 182-6.

[http://dx.doi.org/10.1097/01.CSMR.0000306504.71105.6e] [PMID: 16822339]

[107] Srinivasan K. Antioxidant potential of spices and their active constituents. Crit Rev Food Sci Nutr 2014; 54(3): 352-72.

[http://dx.doi.org/10.1080/10408398.2011.585525]

[PMID: 24188307]

[108] Mittal R, Gupta RL. In vitro antioxidant activity of piperine. Methods Find Exp Clin Pharmacol 2000; 22(5): 271-4.

[http://dx.doi.org/10.1358/mf.2000.22.5.796644]

[PMID: 11031726]

[109] Naidu KA, Thippeswamy NB. Inhibition of human low density lipoprotein oxidation by active principles from spices. Mol Cell Biochem 2002; 229(1-2): 19-23.

[http://dx.doi.org/10.1023/A:1017930708099] [PMID: 11936843]

[110] Verma N, Bal S, Gupta R, Aggarwal N, Yadav A. Antioxidative Effects of Piperine against Cadmium-Induced Oxidative Stress in Cultured Human Peripheral Blood Lymphocytes. J Diet Suppl 2018; 9: 1-12. Epub ahead of print

[http://dx.doi.org/10.1080/19390211.2018.1481485] [PMID 30299203]

[111] Rauscher FM, Sanders RA, Watkins JB III. Effects of piperine on antioxidant pathways in tissues from normal and streptozotocininduced diabetic rats. J Biochem Mol Toxicol 2000; 14(6): 329-34. [http://dx.doi.org/10.1002/1099-0461(2000)14:6<329::AIDJBT5>3.0.CO;2-G] [PMID: 11083086]

[112] Whitehouse S, Chen PL, Greenshields AL, Nightingale M, Hoskin DW, Bedard K. Resveratrol, piperine and apigenin differ in their NADPH-oxidase inhibitory and reactive oxygen speciesscavenging properties. Phytomedicine 2016; 23(12): 1494-503.

[http://dx.doi.org/10.1016/j.phymed.2016.08.011] 27765370]

[113] Sunila ES, Kuttan G. Immunomodulatory and antitumor activity of Piper longum Linn. and piperine. J Ethnopharmacol 2004; 90(2-3): 339-46.

[http://dx.doi.org/10.1016/j.jep.2003.10.016] [PMID: 15013199]

[114] Manayi A, Nabavi SM, Setzer WN, Jafari S. Piperine as a potential anti-cancer agent: A review on preclinical studies. Curr Med Chem 2018; 25(37): 4918-28.

[http://dx.doi.org/10.2174/0929867324666170523120656] [PMID: 28545378]

[115] Rather RA, Bhagat M. Cancer Chemoprevention and Piperine: Molecular Mechanisms and Therapeutic Opportunities. Front Cell Dev Biol 2018; 6: 10.

[http://dx.doi.org/10.3389/fcell.2018.00010] [PMID: 29497610]

[116] Singh J, Reen RK, Wiebel FJ. Piperine, a major ingredient of black and long peppers, protects against AFB1-induced cytotoxicity and micronuclei formation in H4IIEC3 rat hepatoma cells. Cancer Lett 1994; 86(2): 195-200.

[http://dx.doi.org/10.1016/0304-3835(94)90078-7] 7982207]

[117] Reen RK, Wiebel FJ, Singh J. Piperine inhibits aflatoxin B1induced cytotoxicity and genotoxicity in V79 Chinese hamster cells genetically engineered to express rat cytochrome P4502B1. J Ethnopharmacol 1997; 58(3): 165-73.

[http://dx.doi.org/10.1016/S0378-8741(97)00104-9] [PMID: 9421252]

[118] Selvendiran K, Singh JP, Krishnan KB, Sakthisekaran D. Cytoprotective effect of piperine against benzo[a]pyrene induced lung cancer with reference to lipid peroxidation and antioxidant system in Swiss albino mice. Fitoterapia 2003; 74(1-2): 109-15. [http://dx.doi.org/10.1016/S0367-326X(02)00304-0]

[PMID: $12628402]$ 
[119] Selvendiran K, Banu SM, Sakthisekaran D. Protective effect of piperine on benzo(a)pyrene-induced lung carcinogenesis in Swiss albino mice. Clin Chim Acta 2004; 350(1-2): 73-8.

[http://dx.doi.org/10.1016/j.cccn.2004.07.004] [PMID: 15530462]

[120] Selvendiran K, Sakthisekaran D. Chemopreventive effect of piperine on modulating lipid peroxidation and membrane bound enzymes in benzo(a)pyrene induced lung carcinogenesis. Biomed Pharmacother 2004; 58(4): 264-7.

[http://dx.doi.org/10.1016/j.biopha.2003.08.027]

[PMID: 15183854]

[121] Pradeep CR, Kuttan G. Effect of piperine on the inhibition of lung metastasis induced B16F-10 melanoma cells in mice. Clin Exp Metastasis 2002; 19(8): 703-8.

[http://dx.doi.org/10.1023/A:1021398601388] [PMID: 12553376]

[122] Bezerra DP, Castro FO, Alves APNN, et al. In vivo growthinhibition of Sarcoma 180 by piplartine and piperine, two alkaloid amides from Piper. Braz J Med Biol Res 2006; 39(6): 801-7. [http://dx.doi.org/10.1590/S0100-879X2006000600014] [PMID: 16751987]

[123] Bezerra DP, de Castro FO, Alves APNN, et al. In vitro and in vivo antitumor effect of 5-FU combined with piplartine and piperine. J Appl Toxicol 2008; 28(2): 156-63.

[http://dx.doi.org/10.1002/jat.1261] [PMID: 17541943]

[124] Lai LH, Fu QH, Liu Y, et al. Piperine suppresses tumor growth and metastasis in vitro and in vivo in a $4 \mathrm{~T} 1$ murine breast cancer model. Acta Pharmacol Sin 2012; 33(4): 523-30. [http://dx.doi.org/10.1038/aps.2011.209] [PMID: 22388073]

[125] Hwang YP, Yun HJ, Kim HG, et al. Suppression of phorbol-12myristate-13-acetate-induced tumor cell invasion by piperine via the inhibition of PKC $\alpha / E R K 1 / 2$-dependent matrix metalloproteinase-9 expression. Toxicol Lett 2011; 203(1): 9-19.

[http://dx.doi.org/10.1016/j.toxlet.2011.02.013] [PMID: 21354279]

[126] Do MT, Kim HG, Choi JH, et al. Antitumor efficacy of piperine in the treatment of human HER2-overexpressing breast cancer cells. Food Chem 2013; 141(3): 2591-9.

[http://dx.doi.org/10.1016/j.foodchem.2013.04.125] [PMID: 23870999]

[127] Martin-Cordero C, Leon-Gonzalez AJ, Calderon-Montano JM, Burgos-Moron E, Lopez-Lazaro M. Pro-oxidant natural products as anticancer agents. Curr Drug Targets 2012; 13(8): 1006-28. [http://dx.doi.org/10.2174/138945012802009044]

[PMID: 22594470]

[128] Srinivasan MR, Satyanarayana MN. Effect of black pepper (Piper Nigrum Linn.) and piperine on growth, blood constituents and organ eights in rats. Nutr Rep Int 1981; 23: 871-6.

[129] Bhat GB, Chandrasekhara N. Lack of adverse influence of black pepper, its Oleoresin and piperine in the weanling rat. J Food Saf 1986; 7: 215-23.

[http://dx.doi.org/10.1111/j.1745-4565.1986.tb00543.x]
[130] Pachauri M, Gupta ED, Ghosh PC. Piperine loaded PEG-PLGA nanoparticles: Preparation, characterization and targeted delivery for adjuvant breast cancer chemotherapy. J Drug Deliv Sci Technol 2015; 29: 269-82.

[http://dx.doi.org/10.1016/j.jddst.2015.08.009]

[131] Jain S, Meka SRK, Chatterjee K. Engineering a piperine eluting nanofibrous patch for cancer treatment. ACS Biomater Sci Eng 2016; 2: 1376-85.

[http://dx.doi.org/10.1021/acsbiomaterials.6b00297]

[132] Elnaggar YS, Etman SM, Abdelmonsif DA, Abdallah OY. Intranasal piperine-loaded chitosan nanoparticles as brain-targeted therapy in Alzheimer's disease: Optimization, biological efficacy, and potential toxicity. J Pharm Sci 2015; 104: 3544-56.

[http://dx.doi.org/10.1002/jps.24557]

[133] Yusuf M, Khan M, Khan RA, Ahmed B. Preparation, characterization, in vivo and biochemical evaluation of brain targeted Piperine solid lipid nanoparticles in an experimentally induced Alzheimer's disease model. J Drug Target 2013; 21(3): 300-11.

[http://dx.doi.org/10.3109/1061186X.2012.747529]

[PMID: 23231324]

[134] Pentak D. In vitro spectroscopic study of piperine-encapsulated nanosize liposomes. Eur Biophys J 2016; 45(2): 175-86. [http://dx.doi.org/10.1007/s00249-015-1086-x] [PMID: 26493066]

[135] Priprem A, Chonpathompikunlert P, Sutthiparinyanont S, Wattanathorn J. Antidepressant and cognitive activities of intranasal piperine-encapsulated liposomes. Adv Biosci Biotechnol 2011; 2: 10816.

[http://dx.doi.org/10.4236/abb.2011.22017]

[136] Shao B, Cui C, Ji H, et al. Enhanced oral bioavailability of piperine by self-emulsifying drug delivery systems: In vitro, in vivo and in situ intestinal permeability studies. Drug Deliv 2015; 22(6): 740-7. [http://dx.doi.org/10.3109/10717544.2014.898109] [PMID: 24670090]

[137] Boddupalli BM, Ramani R, Subramaniam B, Anisetti RN. In vitro and in vivo evaluation of hepato- protection and anti-ulcer activities of piperine gastro retentive micropspheres. Asian Pac J Trop Biomed 2012; 2: 1237-40.

[http://dx.doi.org/10.1016/S2221-1691(12)60392-X]

[138] Sezgin V, Bayraktar O. assignee. Development of curcumin and piperine loaded double-layered biopolymer based nano delivery systems by using electrospray/coating method. United States patent US 201800284472015 Apr;

[139] Hoffman A, Domb AJ, Elgart A, Cherniakov I. inventors; Formulation and method for increasing oral bioavailability of drugs. United States patent US20140348926 2004 Nov;

[140] Thrower DW inventor. Pharmaceutical oral dose formulation and composition of matter. US2018/0071214 A1 2018 Mar;

[141] Gabriele J, Teris M, Baranowski D. inventors; DELIVRA INC., assignee Transdermal formulations for delivery of capsaicinoids. United States patent US 201802214272018 Sep; 